\title{
Inhalation of vasoactive intestinal peptide in pulmonary hypertension
}

\author{
H.H. Leuchte*, C. Baezner*, R.A. Baumgartner*, D. Bevec ${ }^{\#}$, G. Bacher”, \\ C. Neurohr* and J. Behr*
}

ABSTRACT: Pulmonary hypertension (PH) leads to an increased right ventricular workload, cardiac failure and death. In idiopathic pulmonary arterial hypertension (PAH) the vasodilating vasoactive intestinal peptide (aviptadil) is deficient. The aim of the present study was to test the acute effects on haemodynamics and blood gases, and the safety, of a single dose of inhaled aviptadil in chronic $\mathrm{PH}$.

A total of 20 patients with $\mathrm{PH}$ (PAH in nine, $\mathrm{PH}$ in lung disease in eight and chronic thromboembolic $\mathrm{PH}$ in three) inhaled a single $100-\mu \mathrm{g}$ dose of aviptadil during right-heart catheterisation. Haemodynamics and blood gases were measured.

Aviptadil aerosol caused a small and temporary but significant selective pulmonary vasodilation, an improved stroke volume and mixed venous oxygen saturation. Overall, six patients experienced a pulmonary vascular resistance reduction of $>\mathbf{2 0} \%$. In patients with significant lung disease, aviptadil tended to improve oxygenation.

The pulmonary vasodilating effect of aviptadil aerosol was modest and short-lived, did not cause any side-effects and led to a reduced workload of the right ventricle without affecting systemic blood pressure. Aviptadil inhalation tended to improve oxygenation in patients with significant lung disease. Further studies are needed to evaluate the full therapeutic potential of aviptadil aerosol, including higher doses and chronic treatment.

KEYWORDS: Heart failure, hypertension, peptides, pulmonary, vasodilation ulmonary hypertension $(\mathrm{PH})$ is accompanied by an augmented workload of the right ventricle and leads to significant functional impairment and eventually to right heart insufficiency and death [1-4]. PH occurs without an identifiable cause and in association with known risk factors [1]. Despite increasing options in the treatment of patients with pulmonary arterial hypertension (PAH), there is still a need for further improvement of therapy $[5,6]$. Three classes of compounds have been shown to improve functional capacity in distinct forms of PAH: 1) prostanoids, applied via a continuous parenteral infusion or as an aerosol; 2) selective or dual endothelin receptor antagonists; and 3) the phosphodiesterase $\mathrm{V}$ inhibitor sildenafil [2]. All of these substances are vasoactive, dilating pulmonary vessels and consequently alleviating right ventricular stress [7]. However, it is widely accepted that the long-term results of monotherapy are not fully satisfactory. Consequently, various combination therapies are being tested in clinical trials [8-10]. However, even the results of combination therapies need further clarification in terms of efficacy, safety and tolerability. In addition, no specific treatment is approved for the large number of patients who suffer from non-pulmonary arterial $\mathrm{PH}$ (non-PAH). This leaves room for new substances and potential combination partners. The vasoactive intestinal peptide (VIP, or aviptadil) may be such a candidate. In patients with idiopathic PAH, low serum concentrations of VIP but an increased expression of VIP-mediating receptors have been described. These patients seem to benefit from chronic external VIP substitution via an aerosol [11]. However, the role of aviptadil substitution in other forms of $\mathrm{PH}$ has not been evaluated. Aerosolisation of vasodilators is beneficial in severe $\mathrm{PH}$ of different origins, reducing or avoiding systemic or local side-effects. Moreover, this mode of application has been suggested in order to promote pulmonary and intrapulmonary selectivity to avoid further deterioration of gas exchange [12], especially in chronic hypoxaemia and/or lung disease.

In the present open-label study, it was hypothesised that the pulmonary vasodilative effects of aerosolised aviptadil are not restricted to idiopathic PAH, but can be observed in different forms of $\mathrm{PH}$. The current authors evaluated the
AFFILIATIONS

*Division of Pulmonary Diseases, Dept of Internal Medicine I, Ludwig Maximilians University, Klinikum Grosshadern, Munich, Germany, and "mondoBIOTECH, Basel,

Switzerland.

CORRESPONDENCE

H.H. Leuchte

Division of Pulmonary Diseases Dept of Internal Medicine I

Ludwig Maximilians University Klinikum Grosshadern Marchioninistr. 15 81377 Munich Germany Fax: 498970958877 E-mail: Hanno.Leuchte@med.unimuenchen.de

\section{Received:}

March 312008

Accepted after revision: July 282008

\section{CLINICAL TRIAL}

This clinical trial is registered in the European Union Drug Regulatory Authories' Clinical Trials (EudraCT) database. EudraCT Number: 2004003757-70

STATEMENT OF INTEREST Statements of interest for H.H. Leuchte, D. Bevec and G. Bacher, and for this study can be found at www.erj.ersjournals.com/misc/ statements.shtml 
tolerability and pulmonary vasodilatory potency of a single dose of inhaled aviptadil during acute right heart catheterisation testing in patients with $\mathrm{PH}$.

\section{METHODS}

Consecutive clinically stable $\mathrm{PH}$ patients $(n=20)$ who were scheduled for right heart catheterisation for clinical reasons were included; those with pulmonary venous $\mathrm{PH}$ were excluded. The present study was approved by the institutional ethical committee of the Ludwig Maximilians University (Munich, Germany) and the German regulatory agency (Bundesinstitut für Arzneimittel und Medizinprodukte, Bonn, Germany). Written informed consent was obtained from all patients. During the screening visit, routine laboratory workup was performed, including a pregnancy test when applicable.

\section{Right heart catheterisation and vasodilator test}

The vasodilator test was carried out as described previously [13]. In order to minimise the effects of any pre-treatment, medication was discontinued $12 \mathrm{~h}$ before testing.

Patients inhaled a single $100-\mu$ g dose of aviptadil after a stable baseline of $\geqslant 15 \mathrm{~min}$. Each inhalation was followed by $1 \mathrm{~h}$ of continuous haemodynamic monitoring, comprising heart rate, systemic arterial pressure, pulmonary arterial pressure $(P \mathrm{pa})$ and transcutaneous arterial oxygen saturation. Mixed venous saturation $\left(S_{\mathrm{v}}, \mathrm{O}_{2}\right)$, pulmonary capillary wedge pressure $\left(P_{\mathrm{pcw}}\right)$ and right atrial pressure were recorded every $15 \mathrm{~min}$. Cardiac output was measured at the same intervals, using triplicate measurements with the thermodilution method (Cardiac Output Computer; Edwards Laboratories, Santa Ana, CA, USA). Cardiac index and pulmonary vascular resistance (PVR) and systemic vascular resistance indices were calculated using standard formulae.

Blood samples for blood gas analysis were drawn from the arterial catheter. Oxygen and carbon dioxide partial pressures ( $\mathrm{Pa}, \mathrm{O}_{2}$ and $\mathrm{Pa}, \mathrm{CO}_{2}$ respectively) as well as $\mathrm{pH}$, were measured (ABL 500; Radiometer, Copenhagen, Denmark). All parameters were recorded at baseline, during the last minute of inhalation and at 15-min intervals.

Adverse events were recorded. At the end of each test, the patient and the physician who had performed right heart catheterisation documented the overall impression of tolerability and efficacy using a numerical scale (1: very good; 2: good; 3: moderate; 4: poor).

\section{VAP (aviptadil)}

Aviptadil is the official international nonproprietary or generic name given to VIP by the World Health Organization in 1997 [14]. It is a fully synthetic form of the 28-amino-acid VIP (Bachem, Bubendorf, Switzerland). Aviptadil was supplied in vials (Wuelfing Pharma GmbH, Gronau, Germany; supplier mondoBIOTECH AG, Basel Switzerland) in an aqueous solution $\left(66.6 \mu \mathrm{g} \cdot \mathrm{mL}^{-1}\right.$ in sterile $\left.0.9 \% \mathrm{NaCl}\right)$ for inhalation. Based on previous experience in humans [11, 15-19] the approved target dose of aviptadil was $100 \mu \mathrm{g}$. A total of $1.5 \mathrm{~mL}$ aviptadil solution was aerosolised over $8 \mathrm{~min}$. In a preceding study, comparable effects were observed with a jet nebuliser (UNI light LC star ${ }^{\circledR}$; PARI, Starnberg, Germany) and an ultrasonic nebuliser

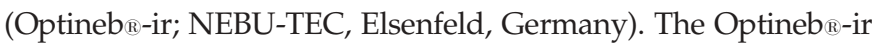
nebuliser was used in the present study.

\section{Statistical analysis}

Data are presented as mean \pm SEM, median \pm SEM or $95 \%$ confidence interval (CI).

Arithmetic means were calculated for all parameters for each patient who completed the protocol as scheduled (patient 7 dropped out). Presuming that the most apparent effect on pulmonary circulation would most probably be paralleled by systemic side-effects such as hypotension, and in order to describe the contribution of the different components that express the haemodynamic effects of a pulmonary vasoactive substance, the most apparent effect (defined as the lowest PVR after inhalation) was recorded as the maximum effect. This was compared with the pre-inhalation values using the $t$-test for paired samples. Uni-factorial ANOVA or the Chi-squared test for nominal or ordinal data was used to compare the overall haemodynamic effect of aviptadil inhalation and to test the influence of previous specific treatment and the diagnostic category. The Dunnett procedure for multiple testing was performed whenever statistical significance was evident. All p-values were two-tailed, and $\mathrm{p}<0.05$ was considered statistically significant.

\section{RESULTS}

\section{Patient characteristics}

The study population comprised 14 females and six males (table 1), aged $58.6 \pm 2.4$ yrs (median 60.5 yrs, 95\% CI 3775.7 yrs). PAH was evident in nine patients, $\mathrm{PH}$ was associated with chronic lung disease in eight and three patients had prior thromboembolism to the lung.

At baseline, patients had signs of advanced precapillary $\mathrm{PH}$ (mean $P_{\text {pa }}\left(\bar{P}_{\text {pa }}\right) \quad 45.2 \pm 2.9 \mathrm{mmHg} ; \quad P_{\text {pcw }} 9.3 \pm 0.76 \mathrm{mmHg}$; cardiac output $4.25 \pm 0.27 \mathrm{~L} \cdot \mathrm{min}^{-1} ; \mathrm{Sv}_{\mathrm{V}} \mathrm{O}_{2} 53.17 \pm 3.58 \%$; PVR $9.2 \pm 0.96$ Wood units (WU)).

Nonspecific treatment for $\mathrm{PH}$ included: digoxin $(n=2)$, diuretics $(n=7)$ and oral anticoagulation $(n=8)$. Specific therapy is detailed in table 1. Other concomitant medications included therapies for arterial hypertension, diabetes mellitus, chronic obstructive pulmonary disease and chronic gastritis, as well as prophylaxis of osteoporosis.

\section{Tolerability and side-effects}

The tolerability of a single $100-\mu \mathrm{g}$ dose of aviptadil was very good in 19 out of 20 patients (tolerability score 1). No sideeffects were observed.

Only one patient developed an adverse effect during or after inhalation of the study drug. This patient (No. 7) withdrew informed consent. After inhaling only a few inhalation cycles, the patient felt anxious, but denied further complaints. This patient had suffered from similar recurrent panic attacks since 1999. This adverse event was probably not related to the study drug. After stopping the inhalation, the patient calmed and was taken to the hospital ward without any further procedure being necessary. 
TABLE 1 Patient characteristics at baseline

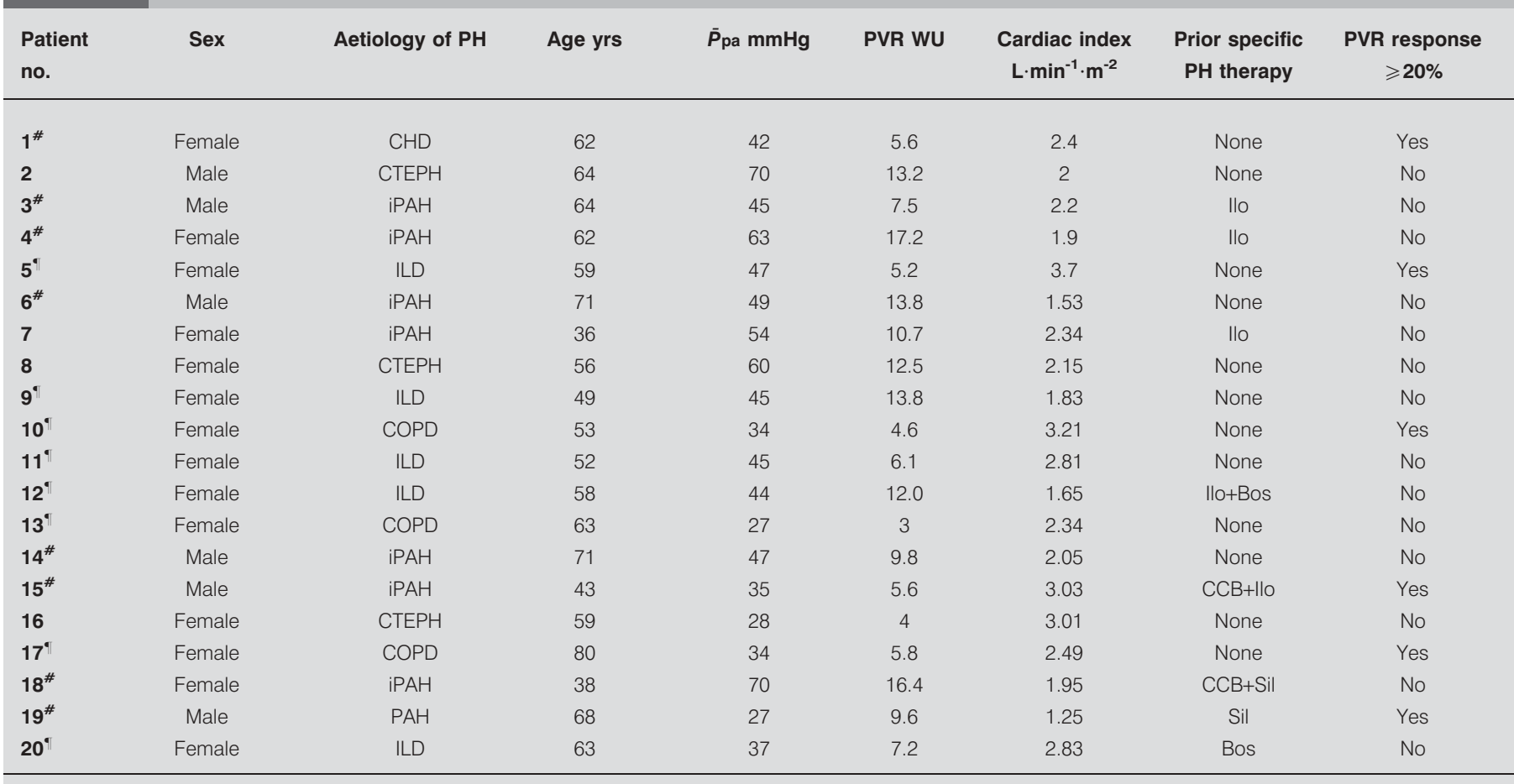

PH: pulmonary hypertension; $\bar{P}$ pa: mean pulmonary arterial pressure; PVR: pulmonary vascular resistance; WU: Wood units; CHD: corrected congenital heart disease CTEPH: nonoperable chronic thromboembolic PH; iPAH: idiopathic pulmonary arterial hypertension (PAH); ILD: chronic interstitial lung disease; COPD: chronic obstructive pulmonary disease; llo: iloprost aerosol; Bos: bosentan; CCB: high-dose calcium channel blockers; Sil: sildenafil. " : PAH patient; " : patient with PH and chronic lung disease.

\section{Efficacy}

Effects on haemodynamics and right heart performance Overall, inhalation of aviptadil resulted in a rapid, small and temporary decrease in $\bar{P}_{\text {pa }}$ (fig. 1a), which was statistically significant immediately after inhalation (change of $-1.7 \mathrm{mmHg}$, $95 \%$ CI $-0.03--3.34 \mathrm{mmHg}, \mathrm{p}<0.05$ ) and $15 \mathrm{~min}$ after the aerosol was stopped (change of $-2.0 \mathrm{mmHg}, \quad 95 \%$ CI $-0.28--3.61 \mathrm{mmHg}, \mathrm{p}<0.05)$. This was paralleled by a significant increase in stroke volume (fig. 1b), 15 min (change $3.5 \mathrm{~mL}, 95 \%$ CI $0.42-6.5 \mathrm{~mL}$ ), $30 \mathrm{~min}$ (change $3.5 \mathrm{~mL}, 95 \%$ CI 0.4-6.5 mL) and $45 \mathrm{~min}$ (change $3.3 \mathrm{~mL}, 95 \%$ CI $0.22-6.3 \mathrm{~mL}$ ) after the aviptadil inhalation was completed. In addition, $\mathrm{S}_{\mathrm{v}, \mathrm{O}_{2}}$ rose immediately after the inhalation ended (relative change $8.8 \%, 95 \%$ CI $4.0-13.7 \%$ ) and $15 \mathrm{~min}$ (relative change $8.5 \%, 95 \%$ CI 3.6-13.3\%), $30 \mathrm{~min}$ (relative change 9\%, 95\% CI 4.2-13.9\%), $45 \mathrm{~min}$ (relative change $9.5 \%, 95 \%$ CI $4.6-14.3 \%$ ) and $60 \mathrm{~min}$ (relative change $8.2 \%, 95 \%$ CI 3.3-13\%) thereafter (all $\mathrm{p}<0.01$ ).

At $15 \mathrm{~min}$ after the end of aerosol inhalation, PVR (change $-0.52 \mathrm{WU}, 95 \%$ CI $-0.04--1.1 \mathrm{WU}, \mathrm{p}>0.05$; fig. 1a) and PVR index (change $-1.49 \mathrm{WU} \cdot \mathrm{m}^{-2}, 95 \% \mathrm{CI}-0.26--2.72 \mathrm{WU} \cdot \mathrm{m}^{-2}$, $p>0.05$ ) were reduced, but this effect did not reach statistical significance. Systemic arterial pressures, cardiac output, cardiac index and right atrial or pulmonary capillary pressures and cardiac frequency $(f c)$ did not change significantly.

A reduction in PVR of $>20 \%$ was observed in six patients (table 1), comprising three PAH patients (No. 1, 15 and 19) and three with $\mathrm{PH}$ and chronic lung disease (No. 5, 17 and 10).
The haemodynamic response was not influenced by any comedication, sex or age.

\section{Effects on blood gas analysis}

During the last $1 \mathrm{~min}$ of inhalation, $\mathrm{Pa}_{1} \mathrm{O}_{2}$ rose from 66.9 to $75.2 \mathrm{mmHg}$ (change $8.3 \mathrm{mmHg}$, 95\% CI $-6.2-22.9 \mathrm{mmHg}$, $\mathrm{p}>0.05)$, whereas $\mathrm{Pa}_{1} \mathrm{CO}_{2}$ was unchanged (42.9 to $43.7 \mathrm{mmHg}$; change $0.75 \mathrm{mmHg}, 95 \% \mathrm{CI}-0.62-2.19 \mathrm{mmHg}, \mathrm{p}>0.05)$. This was paralleled by a decrease in the alveolar-arterial oxygen tension difference $\left(P \mathrm{~A}-\mathrm{a}, \mathrm{O}_{2}\right)$ from $29.58 \mathrm{mmHg}(95 \% \mathrm{CI} 23.13-36 \mathrm{mmHg})$ to $17.63 \mathrm{mmHg}$ ( $95 \% \mathrm{CI} 0.83-36.1 \mathrm{mmHg}$; $\mathrm{p}=0.06$ ). During the observation period only minor changes were observed.

\section{Maximum effects}

While $14(74 \%)$ patients showed the most apparent haemodynamic response within $30 \mathrm{~min}$ after the end of the drug application, the most apparent effect was observed in the second half of the observation period in five patients (data not shown). The maximum effect during the treatment and observation period was calculated. While $\bar{P}_{\text {pa }}$ (change $-1.84 \mathrm{mmHg} ; 95 \%$ CI $0.2-3.48 \mathrm{mmHg}, \mathrm{p}<0.05$ ), PVR (change $-1.0 \mathrm{WU} ; 95 \% \mathrm{CI}-0.53--1.4 \mathrm{WU}, \mathrm{p}<0.001$ ) and $f \mathrm{C}$ (change $-3.2 \mathrm{~min}^{-1}, 95 \%$ CI $-1.45--4.99 \mathrm{~min}^{-1}, \mathrm{p}=0.01$ ) were reduced, cardiac output (change $0.23 \pm 0.1 \mathrm{~L} \cdot \mathrm{min}^{-1} ; 95 \%$ CI $0.01-$ $0.46 \mathrm{~L} \cdot \mathrm{min}^{-1}, \mathrm{p}<0.05$ ), cardiac index (change $0.12 \mathrm{~L} \cdot \mathrm{min}^{-1} \cdot \mathrm{m}^{-2}$; $95 \%$ CI $\left.0.01-0.25 \mathrm{~L} \cdot \mathrm{min}^{-1} \cdot \mathrm{m}^{-2} ; \mathrm{p}<0.05\right)$ and stroke volume (change $5.5 \mathrm{~mL} ; 95 \%$ CI $2.47-8.61 \mathrm{~mL}, \mathrm{p}=0.01$ ) increased significantly (fig. 2). At the time of the maximum haemodynamic 

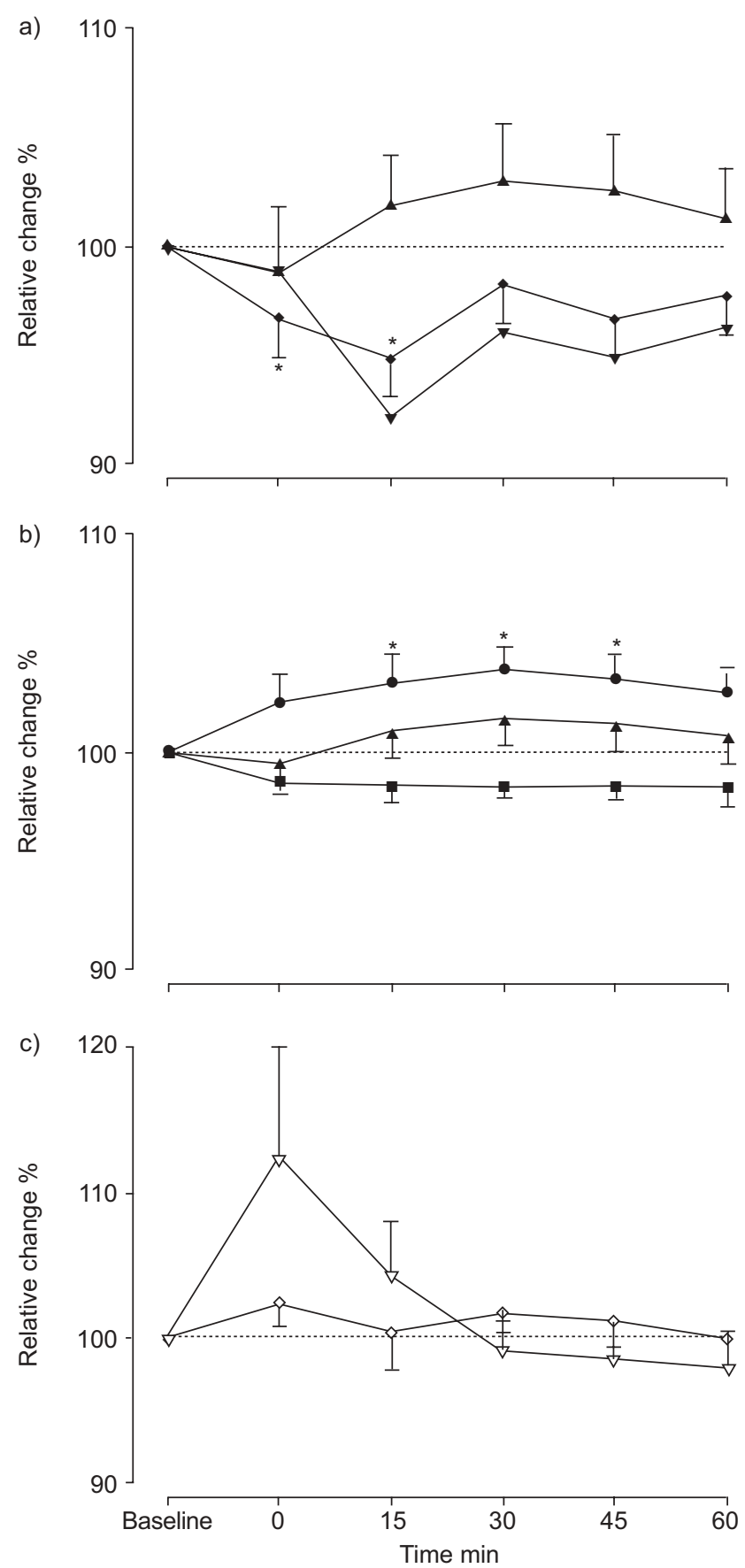

FIGURE 1. The time-dependent effects of a single $100-\mu \mathrm{g}$ dose of aviptadil on a) pulmonary haemodynamics, b) right-heart performance and c) blood gases. - : mean pulmonary artery pressure; $\mathbf{\Lambda}$ : cardiac output; $\mathbf{\nabla}$ : pulmonary vascular resistance; $\bullet$ : stroke volume; $\mathbf{\square}$ : cardiac frequency; $\nabla$ : arterial oxygen tension; $\diamond$ : arterial carbon dioxide tension. ...........: baseline. ${ }^{*}: p<0.05$ versus baseline.

effect, blood gases (not shown) and mean systemic arterial pressure were unchanged compared with baseline values (97.0 to $92.6 \mathrm{mmHg}, \mathrm{p}>0.05)$.

\section{Subgroup analysis}

The largest subgroups of $\mathrm{PAH}$ patients and those with $\mathrm{PH}$ and associated chronic lung diseases (eight patients analysed in each) were analysed separately.

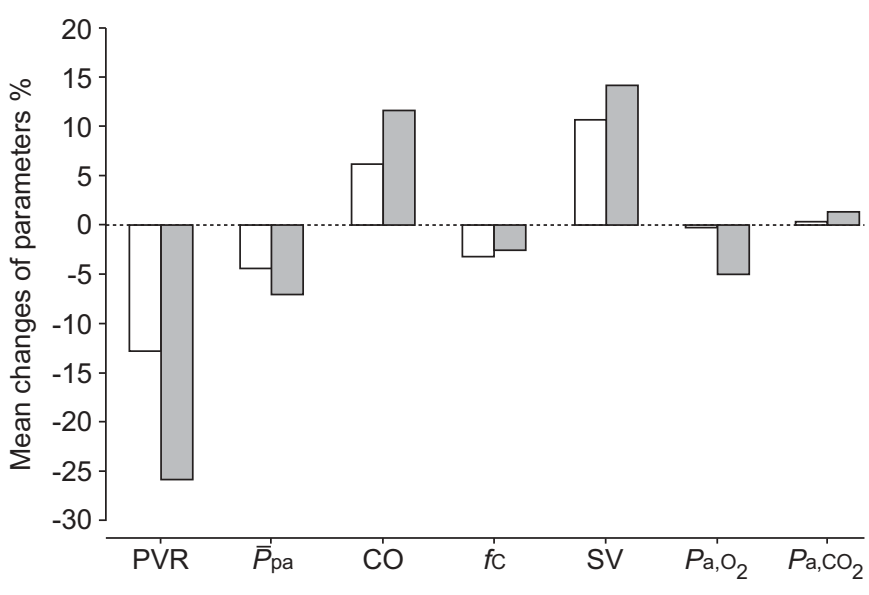

FIGURE 2. Maximum changes in measured parameters $0-60$ min after a single inhaled 100- $\mu \mathrm{g}$ dose of aviptadil. PVR: pulmonary vascular resistance $\bar{P}$ pa: mean pulmonary arterial pressure; $\mathrm{CO}$ : cardiac output; $f \mathrm{C}$ : cardiac frequency; $\mathrm{SV}$ : stroke volume; $\mathrm{Pa}_{\mathrm{a}} \mathrm{O}_{2}$ : arterial oxygen partial pressure; $\mathrm{Pa}_{1} \mathrm{CO}_{2}$ : arterial carbon dioxide partial pressure. $\square$ : changes in whole study group; $\square$ : changes in subjects with a reduction in PVR of $>20 \%(n=6)$.

The latter patients were more often hypercapnic $\left(\mathrm{Pa}_{\mathrm{a}}, \mathrm{CO}_{2}\right.$ $37.6 \pm 2.05$ versus $50.7 \pm 3.8 \mathrm{mmHg}, \mathrm{p}<0.05)$ but all other parameters did not differ significantly between these groups.

In PAH patients, the most apparent effects of aviptadil inhalation included reductions in: $\bar{P}_{\mathrm{pa}}$ (change $-2.43 \mathrm{mmHg}$, 95\% CI -5.9-1.03 mmHg, $\mathrm{p}>0.05$ ); PVR (change $-1.54 \mathrm{WU}, 95 \%$ $\mathrm{CI}-1.1--2 \mathrm{WU}, \mathrm{p}<0.001$ ) and $f \mathrm{C}$ (change $-2.86 \mathrm{~min}^{-1}, 95 \% \mathrm{CI}$ $-6.0-0.18 \mathrm{~min}^{-1}, \mathrm{p}>0.05$ ). Cardiac output (change $0.57 \mathrm{~L} \cdot \mathrm{min}^{-1}$, 95\% CI $0.17-1.1 \mathrm{~L} \cdot \mathrm{min}^{-1}, \mathrm{p}<0.05$ ), cardiac index (change $0.31 \mathrm{~L} \cdot \mathrm{min}^{-1} \cdot \mathrm{m}^{-2}, 95 \%$ CI $\left.0.01-0.6 \mathrm{~L} \cdot \mathrm{min}^{-1} \cdot \mathrm{m}^{-2}, \mathrm{p}<0.05\right)$ and stroke volume (change $4.1 \mathrm{~mL}, 95 \%$ CI 2.03-17.04 mL, p<0.05) increased significantly compared with baseline values. Mean systemic arterial pressure was not significantly affected $(95.9 \pm 4.3$ to $89.5 \pm 5.4 \mathrm{mmHg}, \mathrm{p}>0.05)$.

In this group, $\mathrm{Pa}_{1} \mathrm{O}_{2}$ (69.5 to $64.5 \mathrm{mmHg}$ ), $\mathrm{Pa}_{1} \mathrm{CO}_{2}$ (37.8 to $38.5 \mathrm{mmHg}$ ) and $\mathrm{PA}-\mathrm{a}, \mathrm{O}_{2}$ (28.61 to $34.81 \mathrm{mmHg}$ ) were not significantly affected (all $\mathrm{p}>0.05$ ).

In patients with $\mathrm{PH}$ and chronic lung disease, aviptadil inhalation reduced $\bar{P}_{\text {pa }}$ (change $-2.14 \mathrm{mmHg} ; 95 \%$ CI -5.9$1 \mathrm{mmHg}, \mathrm{p}>0.05$ ), PVR (change $-0.86 \mathrm{WU} ; 95 \%$ CI $-1.7-0.24$ WU, $\mathrm{p}<0.05$ ) and $f C$ (change $-4.7 \mathrm{~min}^{-1}, \quad 95 \%$ CI $\left.-0.73--8.7 \mathrm{~min}^{-1}, \mathrm{p}<0.05\right)$. In parallel, increases were observed in cardiac output (change $0.08 \mathrm{~L} \cdot \mathrm{min}^{-1}, 95 \%$ CI $-0.13-$ $0.29 \mathrm{~L} \cdot \mathrm{min}^{-1}$ ), cardiac index (change $0.04 \mathrm{~L} \cdot \mathrm{min}^{-1} \cdot \mathrm{m}^{-2}, 95 \% \mathrm{CI}$ $-0.1-0.18 \mathrm{~L} \cdot \mathrm{min}^{-1} \cdot \mathrm{m}^{-2}$; all $\mathrm{p}>0.05$ ) and stroke volume (change $4.1 \mathrm{~L} \cdot \mathrm{min}^{-1}, 95 \%$ CI $\left.2.41-5.75 \mathrm{~mL}, \mathrm{p}<0.01\right)$. Mean systemic arterial pressure was not significantly affected $(99.3 \pm 7.6$ to $98.1 \pm 4.6 \mathrm{mmHg}, \mathrm{p}>0.05)$.

In patients with chronic lung disease and $\mathrm{PH}, \mathrm{Pa}_{1} \mathrm{O}_{2}$ increased by $4.9 \mathrm{mmHg}(95 \%$ CI $0.81-9.02 \mathrm{mmHg})$ from 63.3 to $68.2 \mathrm{mmHg}(\mathrm{p}<0.05)$, whereas $\mathrm{Pa}_{1} \mathrm{CO}_{2}$ was unaltered $(49.4$ to $49 \mathrm{mmHg}, \quad \mathrm{p}>0.05)$. Accordingly, $\mathrm{PA}-\mathrm{a}, \mathrm{O}_{2}$ declined from $23.13 \mathrm{mmHg}(95 \%$ CI $12.72-33.54 \mathrm{mmHg})$ to $6.88 \mathrm{mmHg}$ (95\% CI 1.67-12.1 mmHg; $\mathrm{p}<0.05)$. 


\section{DISCUSSION}

The present trial describes for the first time the acute effects on haemodynamics and blood gases, as well as the tolerability, of a single $100-\mu \mathrm{g}$ inhaled dose of aviptadil in a mixed group of patients with moderate to severe PH. Aviptadil was well tolerated, acted as a weak pulmonary selective vasodilator and alleviated right heart strain. These effects were comparable in the PAH and the non-PAH group. Additionally, aviptadil tended to improve oxygenation in patients with chronic lung disease.

Although the haemodynamic effects on pulmonary circulation and gas exchange were statistically significant and in their entirety may be beneficial, these effects were modest and shortlived and of questionable clinical relevance. Further studies are necessary to evaluate the role of aviptadil as a new therapeutic option in the field of $\mathrm{PH}$.

Currently, iloprost is the only approved therapy administered as an aerosol by the European Medicines Agency and the US Food and Drug Administration as a therapy for patients with idiopathic PAH [20]. Still, there is ongoing interest in the development of new inhalational therapies in the field of $\mathrm{PH}$ [7].

The multiple biological effects of VIP, for example the inhibition of platelet activation and the anti-proliferative and relaxant effect on smooth muscle cells, seem to make this substance an attractive therapeutic option in the field of $\mathrm{PH}$ $[19,21,22]$. In addition, patients with idiopathic PAH have lower levels of serum VIP but increased receptor expression in the pulmonary vessels [11]. Compensating this deficit led to pulmonary vasodilation in eight patients with idiopathic PAH during short-term application of VIP [11].

In the present study, aviptadil caused a modest and short-lived pulmonary vasodilation without affecting systemic blood pressure. $f C$ tended to be lower after the inhalation. Physiologically, VIP increases $f C$ [23]. In the present aviptadil aerosol study, stroke volume increased and $f C$ decreased while cardiac output showed a tendency to increase. The current authors interpret these phenomena as signs of alleviated right heart strain. Systemic vasodilation has still to be considered in the context of administration of vasoactive drugs in $\mathrm{PH}$. This is also true for aviptadil, since the i.v. application of VIP leads to systemic vasodilation and decrease in blood pressure [23]. Presuming that the most apparent effect on pulmonary circulation would most likely disclose systemic side-effects (including hypotension), an analysis of the maximum effect of aviptadil inhalation was performed. Despite a significant improvement in $\bar{P}_{\mathrm{pa}}$, cardiac output, $\mathrm{S}_{\mathrm{v}} \mathrm{O}_{2}$ and $\mathrm{PVR}$, systemic arterial pressure was not significantly affected. The observation that systemic side-effects, such as arterial hypotension, can be avoided by aerosol application has been demonstrated previously [12, 20, 24]. OLSCHEWSKI et al. [12] reported that aerosolisation of prostacyclin $\left(\mathrm{PGI}_{2}\right)$ minimises its systemic side-effects. While i.v. administration led to systemic vasodilation and an increased $f C$, these effects were not observed during inhalation of $\mathrm{PGI}_{2}$. Moreover, aerosolisation of $\mathrm{PGI}_{2}$ also improved pulmonary gas exchange by reducing pulmonary shunt flow in patients with $\mathrm{PH}$ complicating pulmonary fibrosis [12].

In accordance with this, the present authors observed a tendency towards an improved oxygenation with an increase in $\mathrm{Pa}, \mathrm{O}_{2}$ and a decrease in $\mathrm{PA}-\mathrm{a}, \mathrm{O}_{2}$. This transient effect was statistically significant in patients with chronic lung disease, suggesting a homogenisation of ventilation/perfusion distribution caused by aviptadil inhalation in this group. Again, the effects on gas exchange were short-lived and no conclusion can be reached about any clinical benefit. However, this is a new finding in the context of aviptadil inhalation and it seems to support the rationale for the use of inhaled vasodilators, especially in patients with ventilation/perfusion mismatch [12]. Since $\mathrm{Pa}_{1} \mathrm{CO}_{2}$ was stable and $\mathrm{PA}-\mathrm{a}, \mathrm{O}_{2}$ decreased in these patients, the possibility that these effects were caused by hyperventilation can be excluded, hence the present authors suggest that improved oxygenation resulted from an improved ventilation/perfusion distribution.

Inhalation of aviptadil has been suggested as a novel approach in idiopathic PAH before. PETKOV et al. [11] concluded that patients with idiopathic PAH lack VIP and have a compensatory upregulation of receptor expression in the pulmonary vasculature, as an attempt to counter-regulate VIP deficiency. Subsequently, eight patients with idiopathic PAH were treated and PETKOV et al. [11] observed an acute and a chronic effect of aerosolised aviptadil. During an acute challenge with a single $100-\mu \mathrm{g}$ dose of aviptadil during right heart catheterisation, a $\bar{P}$ pa reduction of $10 \mathrm{mmHg}$ and an increase of cardiac output of $0.8 \mathrm{~L} \cdot \mathrm{min}^{-1}$ were observed. Chronic treatment with aviptadil comprised four inhalations per day, equalling a daily dose of $200 \mu \mathrm{g}$. After a period of 12 weeks a significant improvement of the 6-min walk test was noted [11]. Although the present authors administered the same dose of aviptadil, comparable strong effects with regard to pulmonary vasodilation were not seen. However, in the PAH group the increase in cardiac output $\left(\sim 0.6 \mathrm{~L} \cdot \mathrm{min}^{-1}\right)$ was comparable.

The modest vasorelaxant effect of a single $100-\mu \mathrm{g}$ aviptadil inhalation may not reflect the full therapeutic potential of this drug. Additional aspects support the rationale for further clinical trials of aerosolised aviptadil in the field of $\mathrm{PH}$. Recently, SAID et al. [25] provided experimental evidence that VIP is involved in the proliferation process of pulmonary vascular smooth muscle. They were able to demonstrate that VIP deficiency leads to moderately severe $\mathrm{PH}$ in male mice lacking the VIP gene [25]. This observation may justify the speculation that chronic treatment with aviptadil positively influences the remodelling process in the pulmonary vasculature in the context of $\mathrm{PH}$.

The current study has clear limitations. One is that a formal dose-response curve was not performed, and this limits interpretation of the data with regard to the maximum haemodynamic efficiency and potential side-effects of the substance. However, regulatory authorities were only willing to approve a maximum single dose of $100 \mu \mathrm{g}$, since this has previously been reported to be safe. Another limitation is that the present study was conducted in an open-label design, without a placebo group, in a nonrandomised fashion. For this reason, the chance that the haemodynamic effects and the effects on gas exchange were spontaneous fluctuations from baseline cannot be excluded. Also, the effects of aviptadil were not compared to other vasoactive substances, and the current authors are not able to present the results of long-term treatment with aviptadil. Finally, the current authors cannot 
provide data about the stability of aviptadil within the lungs after inhalation. Since the structure of aviptadil is prone to proteolysis, this may be an important limitation of this therapeutical approach. A liposomal formulation of aviptadil has been suggested to overcome this limitation in animal models of arterial hypertension [22]. However, aerosolisation of aviptadil in an aqueous solution has been shown to be efficient in $\mathrm{PH}$ before [11], although this approach may necessitate higher doses of aviptadil.

Aviptadil aerosol is well tolerated after a single application. Its acute effects on pulmonary haemodynamics and gas exchange were modest and short-lived and may not reflect the full potential of this substance. Since aviptadil focuses on a new and exclusive pathway, this compound is still an interesting adjunct approach. Further studies with higher doses and longterm treatment are necessary to clarify the role of aviptadil as a future treatment option in this devastating disease.

\section{REFERENCES}

1 Simonneau G, Galie N, Rubin LJ, et al. Clinical classification of pulmonary hypertension. J Am Coll Cardiol 2004; 43: Suppl. 12, 5S-12S.

2 Humbert M, Sitbon O, Simonneau G. Treatment of pulmonary arterial hypertension. $N$ Engl J Med 2004; 351: 1425-1436.

3 Voelkel NF, Quaife RA, Leinwand LA, et al. Right ventricular function and failure: report of a National Heart, Lung, and Blood Institute working group on cellular and molecular mechanisms of right heart failure. Circulation 2006; 114: 1883-1891.

4 Leuchte $\mathrm{HH}$, Baumgartner RA, Nounou ME, et al. Brain natriuretic peptide is a prognostic parameter in chronic lung disease. Am J Respir Crit Care Med 2006; 173: 744-750.

5 Hoeper MM, Rubin LJ. Update in pulmonary hypertension 2005. Am J Respir Crit Care Med 2006; 173: 499-505.

6 Rubin LJ, Galie N. Pulmonary arterial hypertension: a look to the future. J Am Coll Cardiol 2004; 43: Suppl. 12, 89S-90S.

7 Voswinckel R, Enke B, Reichenberger F, et al. Favorable effects of inhaled treprostinil in severe pulmonary hypertension: results from randomized controlled pilot studies. $J$ Am Coll Cardiol 2006; 48: 1672-1681.

8 McLaughlin VV, Oudiz RJ, Frost A, et al. Randomized study of adding inhaled iloprost to existing bosentan in pulmonary arterial hypertension. Am J Respir Crit Care Med 2006; 174: 1257-1263.

9 Hoeper MM, Leuchte H, Halank M, et al. Combining inhaled iloprost with bosentan in patients with idiopathic pulmonary arterial hypertension. Eur Respir J 2006; 28: 691-694.

10 Humbert M, Barst RJ, Robbins IM, et al. Combination of bosentan with epoprostenol in pulmonary arterial hypertension: BREATHE-2. Eur Respir J 2004; 24: 353-359.
11 Petkov V, Mosgoeller W, Ziesche $\mathrm{R}$, et al. Vasoactive intestinal peptide as a new drug for treatment of primary pulmonary hypertension. J Clin Invest 2003; 111: 1339-1346.

12 Olschewski H, Ghofrani HA, Walmrath D, et al. Inhaled prostacyclin and iloprost in severe pulmonary hypertension secondary to lung fibrosis. Am J Respir Crit Care Med 1999; 160: 600-607.

13 Leuchte $\mathrm{HH}$, Schwaiblmair M, Baumgartner RA, Neurohr CF, Kolbe T, Behr J. Hemodynamic response to sildenafil, nitric oxide, and iloprost in primary pulmonary hypertension. Chest 2004; 125: 580-586.

14 World Health Organization. Proposed International Nonproprietary Names List 78. WHO Drug Information Vol. 11. Geneva, World Health Organization, 1997; pp. 265-297.

15 Bundgaard A, Enehjelm SD, Aggestrup S. Pretreatment of exercise-induced asthma with inhaled vasoactive intestinal peptide (VIP). Eur J Respir Dis Suppl 1983; 128: 427-429.

16 Barnes PJ, Dixon CM. The effect of inhaled vasoactive intestinal peptide on bronchial reactivity to histamine in humans. Am Rev Respir Dis 1984; 130: 162-166.

17 Crimi N, Palermo F, Oliveri R, et al. Effect of vasoactive intestinal peptide (VIP) on propranolol-induced bronchoconstriction. J Allergy Clin Immunol 1988; 82: 617-621.

18 Altiere RJ, Kung M, Diamond L. Comparative effects of inhaled isoproterenol and vasoactive intestinal peptide on histamine-induced bronchoconstriction in human subjects. Chest 1984; 86: 153-154.

19 Anaid S, Petkov V, Baykuscheva-Gentscheva T, et al. Involvement of endothelial $\mathrm{NO}$ in the dilator effect of VIP on rat isolated pulmonary artery. Regul Pept 2007; 139: 102-108.

20 Olschewski H, Simonneau G, Galie N, et al. Inhaled iloprost for severe pulmonary hypertension. $N$ Engl J Med 2002; 347: 322-329.

21 Cox CP, Linden J, Said SI. VIP elevates platelet cyclic AMP (cAMP) levels and inhibits in vitro platelet activation induced by platelet-activating factor (PAF). Peptides 1984; 5: 325-328.

22 Rubinstein I. Human VIP- $\alpha$ : an emerging biologic response modifier to treat primary pulmonary hypertension. Expert Rev Cardiovasc Ther 2005; 3: 565.

23 Frase LL, Gaffney FA, Lane LD, et al. Cardiovascular effects of vasoactive intestinal peptide in healthy subjects. Am J Cardiol 1987; 60: 1356-1361.

24 Hoeper MM, Schwarze M, Ehlerding S, et al. Long-term treatment of primary pulmonary hypertension with aerosolized iloprost, a prostacyclin analogue. $N$ Engl J Med 2000; 342: 1866-1870.

25 Said SI, Hamidi SA, Dickman KG, et al. Moderate pulmonary arterial hypertension in male mice lacking the vasoactive intestinal peptide gene. Circulation 2007; 115: $1260-1268$ 